\title{
Pengaruh Persentase Serat Bambu terhadap Sifat Fisik dan Mekanik Papan Beton Ringan
}

\author{
Devi Yunita*, Alimin Mahyudin \\ Laboratorium Fisika Material, Jurusan Fisika FMIPA Universitas Andalas \\ Kampus Unand, Limau Manis,Padang, 25163 \\ *deviyunita11@gmail.com
}

\begin{abstract}
ABSTRAK
Telah dilakukan penelitian tentang pengaruh persentase serat bambu terhadap sifat fisik dan mekanik papan beton ringan. Sifat fisik dan mekanik yang diuji meliputi densitas, daya serap air, porositas, kuat lentur dan kuat tekan. Penelitian ini menggunakan metode two dimensional reinforcement sebagai tata letak dan arah serat dengan variasi serat bambu yang digunakan sebesar $0 \% ; 0,6 \% ; 1,2 \% ; 2,5 \%$ dan $5 \%$ dari volume cetakan. Ketebalan papan beton ringan yang dibuat sebesar $1 \mathrm{~cm}$. Kuat lentur dan kuat tekan menggunakan Universal Testing Machine (UTM). Hasil menunjukkan bahwa komposisi optimum serat 2,5\% menghasilkan nilai kuat lentur sebesar $56,25 \mathrm{kgf} / \mathrm{cm}^{2}$, sedangkan nilai kuat tekan bernilai 91 $\mathrm{kgf} / \mathrm{cm}^{2}$. Selanjutnya, untuk nilai densitas diperoleh sebesar $1,43 \mathrm{~g} / \mathrm{cm}^{3}$, sedangkan nilai daya serap air, yaitu $16,61 \%$ dan nilai porositas sebesar 23,7\%. Papan beton ringan yang dihasilkan telah memenuhi standar mutu ISO 8335, JIS A 5417 dan SNI 03-2104 untuk densitas, sedangkan kuat lentur telah sesuai standar mutu SNI 03-2104.

Kata kunci: kuat lentur, kuat tekan, papan beton ringan, serat bambu
\end{abstract}

\section{ABSTRACT}

The research about the influence of bamboo fiber percentage on the physical and mechanical properties of lightweight concrete board has been conducted. The physical and mechanical properties such as density, water absorption, porosity, flexural strength and compressive strength were determined. The research using the two dimensional reinforcement method as layout and fiber direction with bamboo fiber variation of $0 \% ; 0.6 \% ; 1.2 \% ; 2.5 \%$ and $5 \%$ of composit volume. The thickness of lightweight concrete board made as $1 \mathrm{~cm}$. Flexural and compressive test are performed using a Universal Testing Machine (UTM). The results show that flexural strength is $56.25 \mathrm{kgf} / \mathrm{cm}^{2}$ with optimum fiber percentage of $2.5 \%$, but the compressive strength is $100 \mathrm{kgf} / \mathrm{cm}^{2}$. Then, the density is $1.43 \mathrm{~g} / \mathrm{cm}^{3}$, but water absorption is $16,61 \%$ and porosity is $23,7 \%$. The lightweight concrete board have been produced of density were based on ISO 8335 standard, JIS A 5417 standard and SNI 03-2104 standard, but the flexural strength were based on SNI 03-2104 standard.

Keywords: flexural strength, compressive strength, lightweight concrete board, bamboo fiber

\section{PENDAHULUAN}

Perkembangan teknologi dibidang material semakin pesat seiring dengan peningkatan dalam permintaan terhadap material komposit. Material komposit menjadi pilihan utama dalam pengembangan produk karna memiliki keunggulan dibandingkan material logam yang digunakan secara konvensional. Selain itu material komposit digunakan secara luas pada bidang transportasi, olahraga dan komponen bahan bangunan (Lukassen dan Meidell, 2003).

Papan GRC (Glass-Fiber Reinforced Cement) merupakan salah satu komponen bahan bangunan yang dapat digunakan sebagai dinding partisi. Papan GRC umumnya terbuat dari material komposit beton dan serat sintetis seperti serat kaca. Serat kaca berfungsi sebagai penguat yang dapat meningkatkan kekuatan lentur, tarik dan tekan sehingga menghasikan material yang kokoh dan ringan. Saat ini material komposit mengalami pergeseran dari penggunaan bahan sintetis menuju bahan alam. Hal ini disebabkan karna bahan sintetis tidak dapat terurai secara alami sehingga terjadinya pencemaran lingkungan hidup. Bahan alam yang biasa digunakan dalam material komposit dapat berupa serat yang berasal dari tumbuhan yaitu serat ijuk (Trisna, 2012), serat eceng gondok (Qorina, 2016) dan serat sabut pinang (Silvia, 2017)

Bambu merupakan salah satu tanaman penghasil serat yang memiliki potensi yang dapat dikembangkan sebagai bahan baku pengganti serat kaca. Bambu memiliki kekuatan tarik 2 kali lebih besar dibandingkan kayu, sedangkan dengan baja memiliki kekuatan tarik 3-4 kali lebih besar sehingga kekuatan tarik bambu sekitar $1280 \mathrm{kgf} / \mathrm{cm}^{2}$ (Morisco, 1999). Oleh karena 
itu, serat bambu berpotensi untuk dimanfaatkan sebagai penguat dalam material komposit khususnya pembuatan papan.

Selain penambahan serat bambu sebagai penguat, beton dalam material komposit juga dapat dimodifikasi pembuatannya dengan menambahan bahan lain seperti foam agent. Penambahan foam agent mampu mengurangi densitas beton sehingga dihasilkan beton ringan dengan densitas sebesar $400-1600 \mathrm{~kg} / \mathrm{cm}^{3}$ (Gregor, 1999). Beton ringan memiliki kuat tekan dibawah 17,5 MPa sehingga sangat cocok digunakan sebagai material non-struktural seperti dinding partisi (Gunawan dkk., 2014).

Penelitian tentang material komposit telah banyak dilakukan seperti penelitian Sesa (2012) pada pembuatan papan semen-gipsum berserat bambu. Serat bambu yang digunakan berasal dari bambu apus dengan fraksi volume serat yang digunakan adalah 5\% serat dan diameter 0,1-0,5 mm. Hasil penelitian menunjukkan bahwa nilai densitas, daya serap air, kuat lentur dan kuat tekan berturut-turut sebesar $1,39 \mathrm{~g} / \mathrm{cm}^{3} ; 20,01 \% ; 25,50 \mathrm{kgf} / \mathrm{cm}^{2}$ dan 122,23 $\mathrm{kgf} / \mathrm{cm}^{2}$. Hidayat dkk. (2016) juga melakukan penelitian mengenai penambahan serat kulit bambu apus pada beton. Pada variasi 0,6\% serat mampu meningkatkan kuat tekan, kuat tarik belah dan kuat lentur beton sebesar 28,86 MPa; 3,30 MPa dan 5,39 MPa.

Murtono (2015) melakukan penelitian menggunakan material komposit, yaitu beton dalam pembuatan bata ringan dengan penambahan foam agent. Perbandingan semen dan pasir yang digunakan dalam adukan beton adalah 1:2, sedangkan foam agent yang digunakan dengan variasi $0 \mathrm{~L} / \mathrm{m}^{3} ; 0,6 \mathrm{~L} / \mathrm{m}^{3} ; 0,8 \mathrm{~L} / \mathrm{m}^{3}$ dan $1,0 \mathrm{~L} / \mathrm{m}^{3}$. Pengeringan beton dilakukan selama 28 hari. Hasilnya diperoleh kuat tekan tertinggi pada beton dengan kandungan foam agent $0,6 \mathrm{~L} / \mathrm{m}^{3}$ menggunakan pasir kuarsa sebesar 4,02 $\mathrm{MPa}$ dan kuat lentur balok beton dengan kandungan foam agent $0,6 \mathrm{~L} / \mathrm{m}^{3}$ menggunakan pasir woro sebesar $0,738 \mathrm{MPa}$.

Selanjutnya penelitian ini menggunakan komposit berpenguat serat bambu dengan matriks beton-foam. Lalu fraksi volum serat divariasikan, sedangkan foam agent fraksi volumnya tetap. Tata letak dan arah serat menggunakan two dimensional reinforcement. Penelitian ini diharapkan serat bambu yang digunakan dapat diperoleh persentase optimum fraksi volum serat sehingga dihasilkan papan beton ringan yang memenuhi standar mutu papan semen.

\section{METODE}

Bahan yang digunakan dalam penelitian ini adalah serat bambu sebagai penguat yang diambil dari kulit bambu apus dan dipotong berukuran panjang $1 \mathrm{~cm}$ dan diameter $0,1-0,5 \mathrm{~mm}$, lalu divariasikan fraksi volum serat sebesar $0 \% ; 0,6 \% ; 1,2 \% ; 2,5 \%$ dan $5 \%$ dari volum cetakan. Matriks yang digunakan adalah beton-foam menggunakan komposisi bahan semen : pasir : air, yaitu $1: 2: 0,4$ dan fraksi volum tetap foam agent sebesar $0,06 \%$, dimana foam (busa) yang dihasilkan menggunakan rasio foam agent : pelarut (air), yakni $1: 40$.

Proses pembuatan papan beton ringan menggunakan cetakan dari plat aluminium berukuran $5 \mathrm{~cm} \times 5 \mathrm{~cm} \times 1 \mathrm{~cm}$ untuk pengujian daya serap air, densitas, porositas dan kuat tekan, sedangkan uji kuat lentur dibuat berukuran $20 \mathrm{~cm} \times 5 \mathrm{~cm} \times 1 \mathrm{~cm}$. Lalu dilakukan persiapan serat dengan memotong kulit bambu apus membentuk bilah-bilah tipis dan dilanjutkan perebusan pada suhu $70^{\circ} \mathrm{C}$ selama 1,5 jam dengan memberikan perlakuan alkali $(\mathrm{NaOH})$ 5\% (Nurkertamanda dan Alvin, 2012). Setelah itu dibilas dengan air untuk menghilangkan kandungan $\mathrm{NaOH}$ yang tersisa, kemudian dikeringkan secara alami dengan diangin-anginkan selama 7 hari dan serat dipotong sesuai dengan ukuran yang telah ditentukan.

Semua komposisi bahan penyusun papan beton ringan ditimbang menggunakan timbangan digital. Adonan beton-foam dibuat dengan mencampurkan semen, pasir dan air serta ditambahkan foam yang terlebih dahulu dibuat dengan mencampurkan foam agent dan air menggunakan mixer. Setelah adonan beton-foam diaduk dan dicampur merata menggunakan sendok semen, lalu adonan dimasukkan sebagian kedalam cetakan yang berbeda ukuran. Selanjutnya ditambahkan serat bambu kedalam cetakan yang sudah diisi sebagian adonan beton-foam. Setelah itu ditambahkan kembali adonan beton-foam hingga membentuk papan beton ringan sesuai dengan ukuran cetakan. Papan beton ringan yang sudah dicetak, dibiarkan mengering didalam cetakan selama 24 jam, lalu dilakukan perawatan hingga 28 hari. Setelah itu, papan dilakukan pengujian terhadap sifat fisik dan mekanik. Hasil pengujian papan 
dibandingkan dengan standar ISO 8335, JIS A 5417 dan SNI 03-2104 sehingga diperoleh papan beton ringan yang sesuai standar mutu papan semen.

\subsection{Pengujian Densitas}

Pengujian densitas sampel uji dilakukan pada kondisi kering. Mula-mula sampel uji ditimbang menggunakan timbangan digital dan dicatat hasilnya sebagai $m$. Selanjutnya dilakukan perhitungan menggunakan Persamaan (1) untuk mendapatkan nilai densitas sampel uji.

$$
\rho=\frac{m}{V}
$$

dengan $\rho$ adalah densitas $\left(\mathrm{g} / \mathrm{cm}^{3}\right), m$ adalah massa sampel kondisi kering $(\mathrm{g})$ dan $V$ adalah volume sampel $\left(\mathrm{cm}^{3}\right)$.

\subsection{Pengujian Daya Serap Air}

Pengujian daya serap air dilakukan pada sampel uji densitas. Mula-mula sampel uji dilakukan perendaman dalam wadah berisi air pada suhu $25^{\circ} \mathrm{C}$ selama 24 jam. Setelah itu sampel uji diangkat dan ditimbang menggunakan timbangan digital dan dicatat hasilnya sebagai $m_{b}$. Setelah itu dilakukan perhitungan menggunakan Persamaan (2) untuk mendapatkan nilai daya serap air.

$$
W A=\frac{m_{b}-m}{m} \cdot 100 \%
$$

dengan $W A$ adalah daya serap air $(\%), m_{b}$ adalah massa basah sampel setelah direndam $(\mathrm{g})$ dan $m$ adalah massa sampel kondisi kering oven $(\mathrm{g})$.

\subsection{Pengujian Porositas}

Pengujian porositas dilakukan pada sampel uji daya serap air sehingga pengujian porositas sekaligus bersamaan dengan uji daya serap air. Perhitungan porositas sampel uji menggunakan Persamaan (3).

$$
P=\frac{m_{b}-m}{V} \cdot \frac{1}{\rho_{a}} 100 \%
$$

dengan $P$ adalah porositas $(\%), m_{b}$ adalah massa basah sampel setelah direndam $(\mathrm{g})$ dan $m$ adalah massa sampel kondisi kering oven $(\mathrm{g}), V$ adalah volume sampel $\left(\mathrm{cm}^{3}\right)$ dan $\rho_{a}$ adalah massa jenis air yaitu $1 \mathrm{~g} / \mathrm{cm}^{3}$.

\subsection{Pengujian Kuat Lentur}

Pengujian kuat lentur menggunakan UTM (Universal Testing Machine) dengan meletakkan sampel uji secara mendatar pada tumpuan. Lalu beban diberikan pada bagian pusat sampel uji seperti diperlihatkan Gambar 1, kemudian dicatat beban maksimum hingga sampel uji patah sebagai nilai $P_{p}$. Setelah itu dilakukan perhitungan nilai kuat lentur menggunakan Persamaan (4).

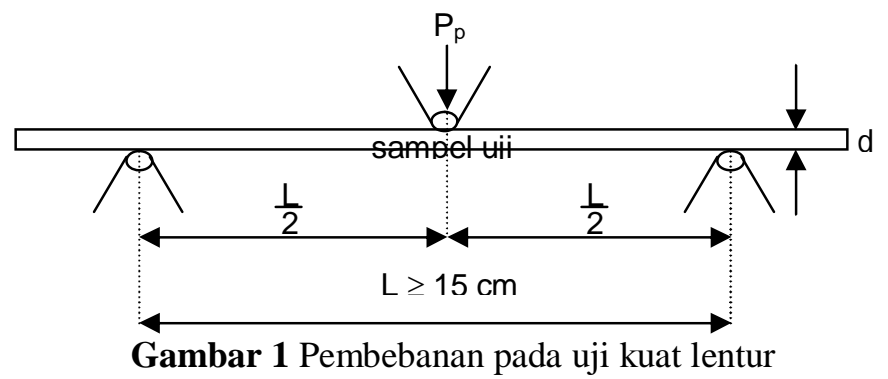




$$
P=\frac{3 P_{p} L}{2 b d^{2}}
$$

dengan $f_{r}$ adalah kuat lentur $\left(\mathrm{kgf} / \mathrm{cm}^{2}\right), P_{p}$ adalah beban patah maksimum $(\mathrm{kgf}), L$ adalah panjang tumpuan $(\mathrm{cm}), b$ adalah lebar sampel $(\mathrm{cm})$ dan $d$ adalah tebal sampel $(\mathrm{cm})$.

\subsection{Pengujian Kuat Tekan}

Pengujian kuat tekan juga menggunakan mesin UTM dengan meletakkan sampel uji pada tumpuan. Lalu sampel uji diberi beban secara vertikal seperti diperlihatkan Gambar 2, kemudian dicatat beban maksimum hingga sampel uji retak sebagai nilai $P_{r}$. Setelah itu dilakukan perhitungan nilai kuat lentur menggunakan Persamaan (5).

$$
f_{c}=\frac{P_{r}}{A}
$$

dengan $f_{c}$ adalah kuat tekan $\left(\mathrm{kgf} / \mathrm{cm}^{2}\right), P_{r}$ adalah beban retak maksimum sampel (kgf) dan $A$ luas penampang atau permukaan yang diberi gaya $\left(\mathrm{cm}^{2}\right)$.

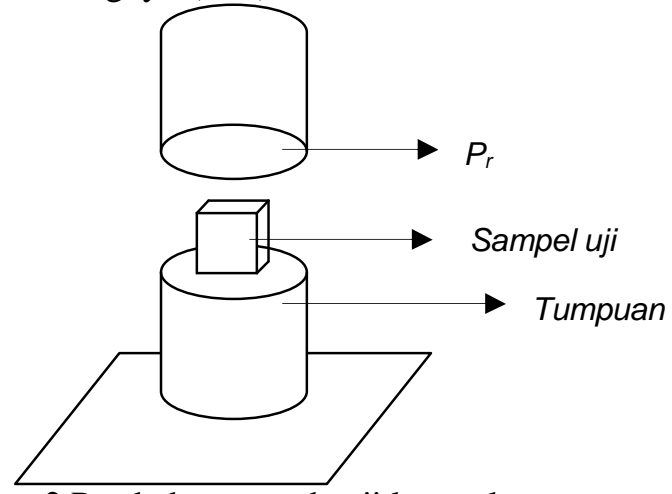

Gambar 2 Pembebanan pada uji kuat tekan

\section{HASIL DAN DISKUSI}

\subsection{Densitas}

Pada Gambar 3 terlihat penurunan nilai densitas hingga $1,27 \mathrm{~g} / \mathrm{cm}^{3}$ pada persentase serat $1,2 \%$ sebagai densitas terendah. Hal ini menunjukkan bahwa serat bambu memiliki densitas yang lebih rendah dari matriks beton-foam sehingga bertambahnya fraksi volum serat, maka berkurangnya fraksi volum matriks beton-foam yang mengakibatkan berkurangnya massa papan dengan volume papan yang tetap. Selanjutnya, nilai densitas mengalami kenaikan hingga $1,48 \mathrm{~g} / \mathrm{cm}^{3}$ pada persentase serat $5 \%$. Ini berarti penambahan serat bambu pada persentase tertentu akan meningkatkan densitas papan. Selain itu, Papan beton ringan serat bambu yang dihasilkan telah sesuai dengan standar mutu papan ISO $8335\left(\geq 1 \mathrm{~g} / \mathrm{cm}^{3}\right)$, JIS A $5417(\geq 1,2$ $\left.\mathrm{g} / \mathrm{cm}^{3}\right)$ dan SNI 03-2104 $\left(\geq 0,57 \mathrm{~g} / \mathrm{cm}^{3}\right)$.

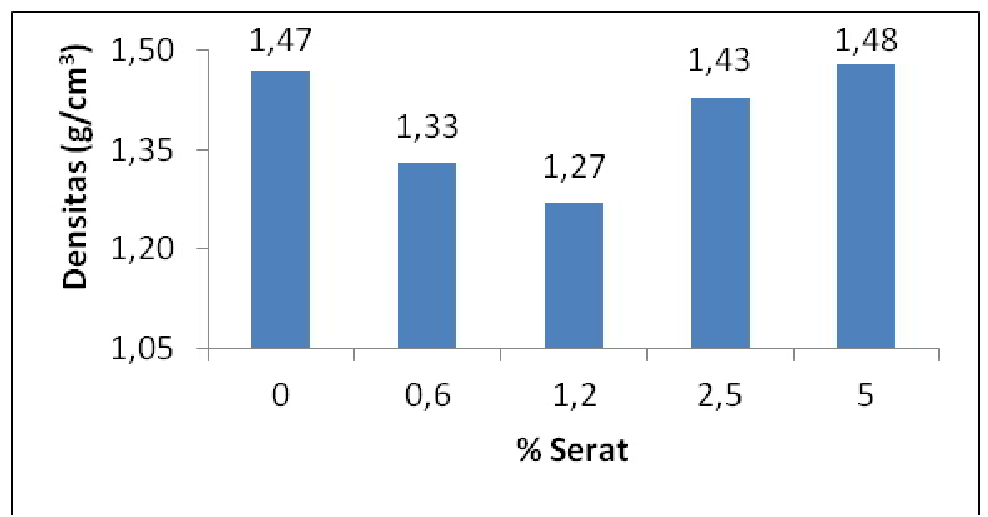

Gambar 3 Densitas rata-rata papan beton ringan serat bambu 


\subsection{Daya Serap Air}

Pada Gambar 4 terlihat nilai daya serap air meningkat hingga 19,19\% pada persentase serat $1,2 \%$ sebagai densitas tertinggi. Hal ini dikarenakan serat bambu mengandung selulosa sebesar 42,4-53,6\%. Haygreen dan Bowyer (1996) menyatakan bahwa selulosa yang terdapat pada filler (serat bambu) papan partikel itu mampu menyerap air karna adanya gaya absorpsi yang merupakan gaya tarik molekul air pada ikatan hidrogen yang terdapat dalam selulosa tersebut.

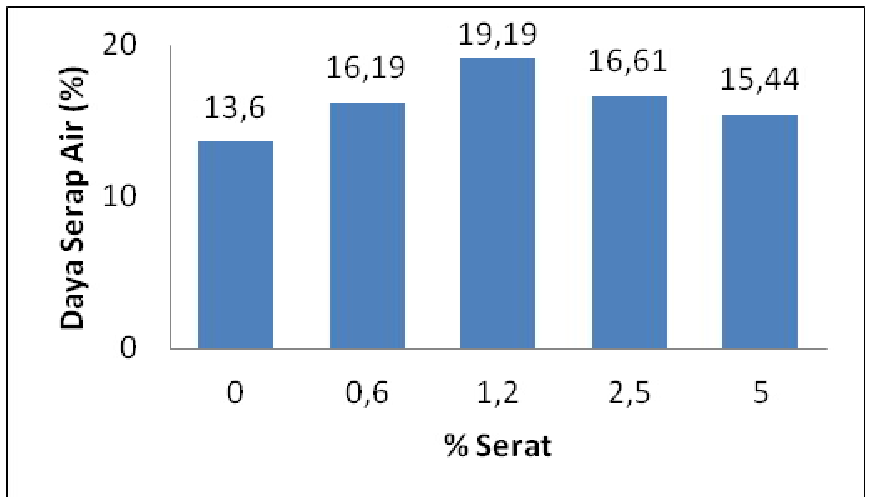

Gambar 4 Daya serap air rata-rata papan beton ringan serat bambu

Densitas berhubungan langsung dengan proporsi ruang kosong dan berpengaruh terhadap sifat fisis dan mekanis. (Hygreen dan Bowyer, 1996). Nilai densitas yang rendah dipengaruhi adanya void pada bentuk penguat (serat bambu) yang tidak seragam sehingga menyebabkan ruang kosong pada ikatan matriks dengan serat. Hal ini membuat aliran air dapat masuk secara kapilarisasi yang berakibat daya serap air menjadi tinggi. Selanjutnya, nilai daya serap air mengalami penurunan hingga $15,44 \%$ pada persentase serat $5 \%$. Ini menunjukkan penambahan serat bambu pada proporsi tertentu menyebabkan daya serap air papan menjadi kecil.

\subsection{Porositas}

Pada Gambar 5 terlihat nilai porositas meningkat hingga 24,84\% pada persentase serat $1,2 \%$. Hal ini menunjukkan bahwa nilai porositas sebanding dengan nilai daya serap air, sedangkan dengan nilai densitas berbanding terbalik. Semakin kecil porositas semakin rendah daya serap air sehingga densitas papan menjadi tinggi. Namun, penambahan serat bambu pada proporsi tertentu menyebabkan porositas papan menjadi menurun hingga $22,75 \%$ pada persentase serat $5 \%$.

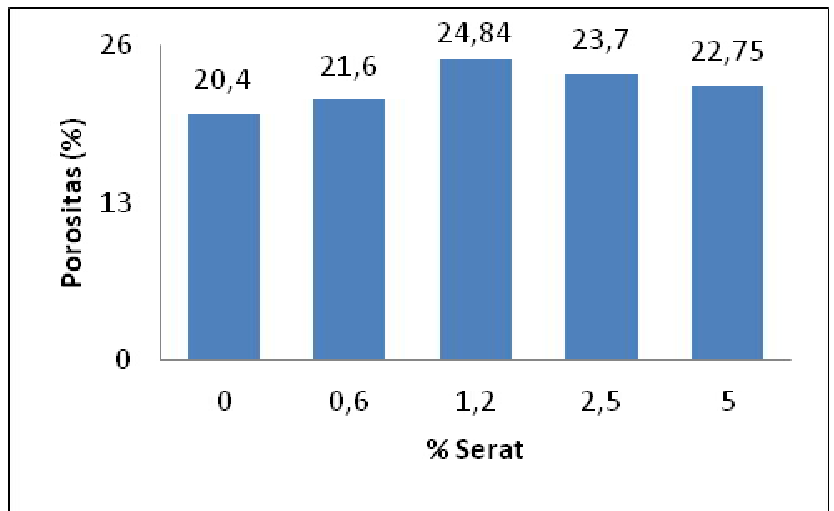

Gambar 5 Porositas rata-rata papan beton ringan serat bambu

\subsection{Kuat Lentur}

Pada Gambar 6 terlihat bahwa nilai kuat lentur meningkat hingga $56,25 \mathrm{~kg} / \mathrm{cm}^{2}$ pada persentase serat $2,5 \%$. Penambahan serat yang melebihi batas maksimum tersebut akan 
menyebabkan kuat lentur menjadi tidak optimum seperti yang terlihat pada kadar serat $5 \%$ yang bernilai $51,75 \mathrm{kgf} / \mathrm{cm}^{2}$. Keadaan ini sesuai dengan pernyataan Haygreen dan Bowyer (1996) yang mengemukakan bahwa densitas berhubungan langsung dengan proporsi ruang kosong dan berpengaruh terhadap sifat fisis dan mekanis yang disebabkan oleh void yang semakin besar sehingga menyebabkan ruang kosong pada ikatan matriks. Selain itu, papan beton ringan yang dihasilkan telah memenuhi standar mutu SNI-03-2104 yang menetapkan nilai kuat lentur, yaitu $\geq 17 \mathrm{~kg} / \mathrm{cm}^{3}$

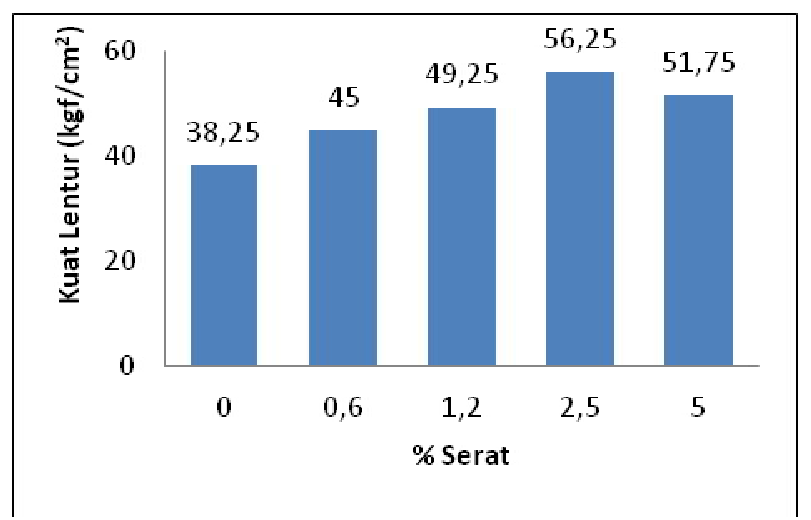

Gambar 6 Kuat lentur rata-rata papan beton ringan serat bambu

\subsection{Kuat Tekan}

Pada Gambar 7 terlihat bahwa persentase serat $0 \%$ atau tanpa serat memiliki kuat tekan terendah sebesar $73,9 \mathrm{kgf} / \mathrm{cm}^{2}$. Selanjutnya nilai kuat tekan yang maksimal diperoleh pada kadar serat $0,6 \%$ yang bernilai $100 \mathrm{kgf} / \mathrm{cm}^{2}$. Penambahan serat yang melebihi batas maksimum tersebut akan membuat papan semakin rapuh karena semakin memperlemah ikatan antar serat dan matriks, akibatnya nilai kuat tekan menjadi kecil.

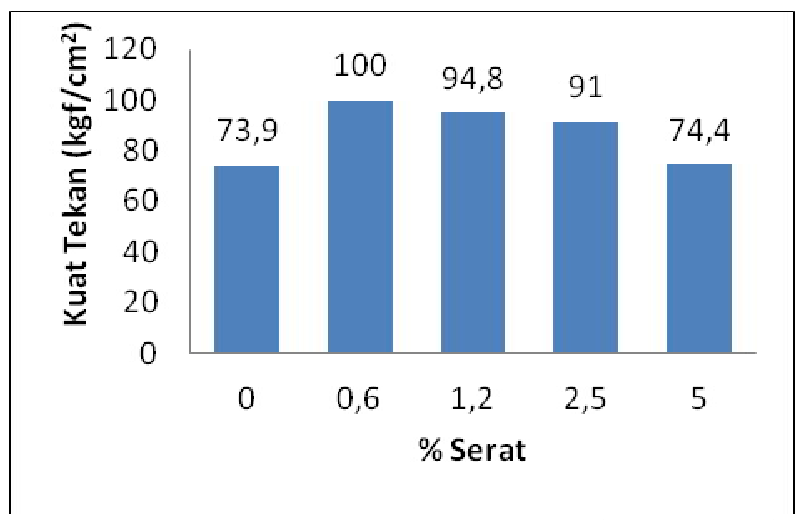

Gambar 7 Kuat tekan rata-rata papan beton ringan serat bambu

\section{KESIMPULAN}

Serat bambu dapat digunakan sebagai bahan baku dalam pembuatan papan beton ringan yang berfungsi sebagai penguat dan berpengaruh terhadap sifat fisik dan mekanik papan beton ringan. Komposisi optimum serat 2,5\% menghasilkan nilai kuat lentur sebesar $56,25 \mathrm{kgf} / \mathrm{cm}^{2}$, sedangkan nilai kuat tekan bernilai $91 \mathrm{kgf} / \mathrm{cm}^{2}$. Selanjutnya, untuk nilai densitas diperoleh sebesar $1,43 \mathrm{~g} / \mathrm{cm}^{3}$, sedangkan nilai daya serap air, yaitu $16,61 \%$ dan nilai porositas sebesar $23,7 \%$. Secara keseluruhan papan beton ringan yang dihasilkan telah memenuhi standar mutu ISO 8335, JIS A 5417 dan SNI 03-2104 untuk densitas, sedangkan kuat lentur telah sesuai standar mutu SNI 03-2104.

\section{DAFTAR PUSTAKA}

Badan Standardisasi Nasional (BSN), 1991, Papan Semen Wol Kayu, J akarta, SNI 03-2104. Gregor, M.J., 1999, Reinforced Concrete Mechanies and Design, Prentice Hall, New Jersey. 
Gunawan, P., Wibowo dan Muttaqin, M.A., 2014, Pengaruh Penambahan Serat Polyethylene pada Beton Ringan dengan Teknologi Foam terhadap Kuat Tekan, Kuat Tarik Belah dan Modulus Elastisitas, e-Jurnal Matriks Teknik Sipil, Jurusan Teknik Sipil Universitas Sebelas Maret Surakarta.

Guralnik, D.B., 1979, Webster's New World Dictionary Second Edition College, William Collins Publisher, Cleveland, Ohio.

Haygreen, J.G. dan Bowyer, J.L., 1996, Hasil Hutan dan Ilmu Kayu, (diterjemahkan oleh: Sucipto, A.H.), Gajah Mada University Press, Yogyakarta.

Hidayat, M.E., Ismeddiyanto dan Kurniawan, A., 2016, Pengaruh Penambahan Serat Kulit Bambu terhadap Sifat Mekanik Beton, Jom FTeknik, Vol. 3, No. 1, Jurusan Teknik Sipil UR.

International Organization for Standardization, 1987, Cement-Bonded Particleboards: Board of Portland or Equivalent Cement Reinforced with Fibrous Wood Particles, Geneva, ISO 8335.

Japanese Standards Association (JSA), 1992, Cement Bonded Particle Boards, Japan, JIS A 5417.

Lukassen, D. dan Meidell, A., 2003, Advanced Materials and Structures and their Fabrication Processes, Edisi Ketiga, Narvik University College, HiN.

Maloney, T.M., 1993, Modern Particle Board and Dry Process Fiberboard Manufacturing, Miller Freeman Publication, San Fransisco, California.

Morisco, 1999, Rekayasa Bambu, Nafiri Offset, Yogyakarta.

Murtono, A., 2015, Pemanfaatan Foam Agent dan Material Lokal dalam Pembuatan Bata Ringan, Jurnal, Jurusan Teknik Sipil UMS.

Nurkertamanda, D. dan Alvin, A., 2012, Desain Proses Pembentukan Serat Bambu sebagai Bahan Dasar Produk Industri Kreatif Berbahan Dasar Serat pada UKM, Jurnal Teknik Industri (J@TI), Vol. 7, No. 3, Jurusan Teknik Industri Undip.

Qorina, U., 2016, Pengaruh Persentase Massa Gipsum dan Serat terhadap Kuat Tekan dan Kuat Lentur Papan Semen-Gipsum Berserat Eceng Gondok, Skripsi, Jurusan Fisika, Universitas Andalas, Padang.

Sesa, D., 2012, Pengaruh Proporsi Semen dengan Gipsum terhadap Sifat Fisis dan Mekanik Papan Semen-Gipsum Berserat Bambu, Skripsi, Jurusan Fisika, Universitas Andalas, Padang.

Silvia, Y., 2012, Pengaruh Persentase Serat Sabut Pinang terhadap Sifat Mekanik dan Fisik Papan Gipsum-Beton, Skripsi, Jurusan Fisika, Universitas Andalas, Padang.

Trisna, H., 2012, Analisa Sifat Fisik dan Mekanik Papan Komposit Gipsum Serat Ijuk dengan Penambahan Boraks, Skripsi, Jurusan Fisika, Universitas Andalas, Padang. 